ESJ Social Sciences

\title{
Can Personality Traits, Risk Attitude, and Demographics Explain Fund Managers' Disposition Effect?
}

\author{
Omar Mzioud, PhD Candidate \\ Siham Meknassi, PhD
}

Center for Doctoral Studies, Institut Supérieur de Commerce et d'Administration des Entreprises (ISCAE), Morocco

Doi:10.19044/esj.2021.v17n32p303

Submitted: 23 August 2021

Accepted: 25 September 2021

Published: 30 September 2021
Copyright 2021 Author(s)

Under Creative Commons BY-NC-ND

4.0 OPEN ACCESS

Cite As:

Mzioud O. \& Meknassi S. (2021). Can Personality Traits, Risk Attitude, and Demographics Explain Fund Managers' Disposition Effect? European Scientific Journal, ESJ, 17 (32), 303. https://doi.org/10.19044/esj.2021.v17n32p303

\begin{abstract}
This paper focuses on the extent to which personality traits, risk attitude, and demographics explain holding losses and cutting gains using survey data collected among equity and bond fund managers. For this purpose, cross-sectional multiple regressions were conducted. This paper argues that holding losses and cutting gains are two independent biases, rather than two sides of the disposition effect. The results show a significant effect of extraversion, openness, risk-taking, professional experience, and university degree on holding losses, and a significant effect of risk perception and gender on cutting gains. This paper contributes to few studies on personality traits and behavioral biases of professional investors, and it may have important practical implications in fund management companies.
\end{abstract}

Keywords: Cutting gains, holding losses, personality traits, risk attitude, fund managers

\section{Introduction}

Since the pioneering work of Shefrin and Statman (1985), a great deal of research works has provided evidence for the disposition effect (Cecchini et al., 2019; Braga \& Fávero, 2017; Wulfmeyer, 2016; Frydman et al., 2014; Singal \& Xu, 2011; Jin \& Scherbina, 2011; Odean, 1998). The disposition effect is the tendency to hold losing positions too long and to sell winning 
positions too soon. It is also known as "holding losses" and "cutting gains". Several explanations have been provided for this bias, which are related to the triptych: prospect theory, mental accounting, and regret avoidance. The prospect theory, developed by Kahneman and Tversky (1979), argues that individuals value gains and losses differently. According to this theory, investors display risk aversion in choices involving gains by selling securities in order to reduce uncertainty, and risk tolerance in choices involving losses by holding securities to avoid realizing these losses. Mental accounting, as introduced by Thaler (1985), suggests that investors separate their investment into segregated "mental" accounts, based on a set of subjective criteria such as the source of money and its destination, instead of taking into account their portfolio as a whole. With regard to regret avoidance, the tendency of investors to regret would delay their decision-making and, thus, discourage them from selling their losing positions.

Psychological literature organizes the differences in the way mental mechanisms drive diverse cognitive processes into stable patterns of emotions and actions defined as personality traits. This literature defines these traits as stable over time and different from one individual to another. In recent research works, the most adopted approach in the analysis of personality traits is the one developed from the pioneering work of Tupes and Christal (1961; 1992) in which a five-factor model is supposed to describe the individuals' psychological characteristics. Generally, the studies that followed those of Tupes and Christal identified the same five factors, namely; neuroticism, extraversion, conscientiousness, openness, and agreeableness.

Neuroticism is often associated with anxiety, shyness, irritability, impulsiveness, depression, anger, and mood swings. Extraversion is generally associated with energetic, sociable, talkative, friendly, gregarious, convivial, low-intellectual individuals who have a good sense of humor. As for conscientious individuals, they are often portrayed as efficient, organized, prepared, reliable, disciplined, and concerned. Openness is associated with individuals of good intellectual level, curious, with great imagination, and inventiveness. Finally, agreeableness is characterized by courtesy, modesty, altruism, confidence, generosity, and warm relationships.

Durand et al. (2013) were among the first to study the relation between personality traits and disposition effect. They found that agreeableness and conscientiousness are positively related to the disposition effect. These authors also found that neuroticism and extraversion positively impact cutting gains, while conscientiousness is negatively related to holding losses. The results reported by Ahmad (2020) show that disposition effect is positively associated with extraversion and conscientiousness. Cecchini et al. (2019) found that disposition effect is positively influenced by extraversion and negatively related to openness and conscientiousness. These authors document that 
disposition effect could be determined by two independent psychological biases: holding losses and cutting gains. Their findings show that holding losses is positively related to openness. Cutting gains is on the one hand negatively associated to both openness and conscientiousness and, on the other hand, positively associated to extraversion.

Examining the impact of risk attitude, Oreng, Yoshinaga and Eid Junior (2021) and Ahmad (2020) reported a positive effect of risk-aversion on the disposition effect. Furthermore, Ahmad (2020) reports a negative moderating effect of risk-aversion on the relation between agreeableness, extraversion, and disposition effect. Moreover, Durand et al. (2013) find that holding losses is positively influenced by risk-taking.

Regarding the impact of demographic characteristics, Rau (2014) concludes that female investors are more prone to the disposition effect. This fact is mainly driven by holding losses. He also concludes that men investors are less loss averse than female. Oreng, Yoshinaga and Eid Junior (2021) find that male investors and investors with higher education are resilient to the disposition effect. Cheng, Lee and Lin (2013) demonstrate that female and mature investors are more vulnerable to the disposition effect. Durand et al. (2013) test the impact of psychological gender on disposition effect. These authors find that masculinity is negatively related to the disposition effect. This outcome was also found for the cutting gains bias. Finally, according to Cueva et al. (2019), disposition effect and cutting gains scores are negatively related to experience.

Let us recall that the disposition effect has usually been viewed as a bias consisting of a single, homogeneous and rigid block, measured by the difference between the proportion of realized gains and losses. In this sense, prospect theory considers the disposition effect as a unitary bias. The objective of this study is to investigate the extent to which personality traits, risk attitude, and demographics explain fund managers' cutting gains and holding losses, which are the two sides of the disposition effect. The analysis of the disposition effect presented in this paper focuses on these two components, which are consistent with recent studies suggesting that cutting gains and holding losses may be separate biases rather than two sides of the same bias (Cecchini et al., 2019; Cueva et al., 2019; Grayson, 2017; Frydman et al., 2014; Durand et al., 2013; Summers \& Duxbury, 2012; Weber \& Welfens, 2007).

\section{Data and Methodology}

To highlight investor behavior, behavioral finance research typically uses two modes of data collection: experiment and questionnaire. It should be noted that the fund managers' community is seen as a closed club. Their workload and psychological pressure allow them limited time and 
concentration budget. Thus, an experimental design is not suitable for fund managers. Moreover, the questionnaire should be designed as short as possible, and formulated in an appropriate language of fund managers. Subsections 2.1, 2.2, and 2.4 present measurement design, data collection, and analysis and data summary respectively.

Overall measurement quality is assessed by testing face and content validity, reliability, and unidimensionality of the scales. Subsection 2.3 details how item analysis is conducted.

In order to test the impact of personality traits, risk attitude and demographics on cutting gains and holding losses, cross-sectional multiple regressions are conducted using the best model selection procedure based on adjusted $\mathrm{R}^{2}$ criterion. This choice is motivated by the simplicity principle or the Occam's razor principle. Typically, there are two ways of selecting variables: selection by optimization and selection based on partial F-test. The selection by optimization consists in producing all the possible combinations of exogenous variables, then choosing the regression which maximizes a quality criterion such as adjusted $\mathrm{R}^{2}$, AIC (Akaike information criterion), and BIC (Bayesian information criterion). Furthermore, the selection based on the partial F-test, such as forward selection, backward selection and stepwise regression, consists in adding a variable if the square of Student's t-statistic (which follows a Fisher's F-distribution) indicates that the associated coefficient is significantly different from 0 . Otherwise, the variable is deleted if its coefficient is not significant. The main objective of this study is to test the impact of the aforementioned independent variables on dependent variables by trying to keep the maximum number of these independent variables and to maximize the adjustment quality of the model. Thus, the selection based on the partial F-test is excluded since it allows only the most significant variables (the most parsimonious model) to be retained. Likewise, criteria based on AIC and BIC are excluded since they favor solutions with few variables.

The selection procedure based on adjusted $\mathrm{R}^{2}$ criterion consists in choosing, among the $2^{\mathrm{p}}-1$ models (where $\mathrm{p}$ is the number of exogenous variables), the model which has the highest adjusted $R^{2}$. The adjusted $R^{2}$ is given by the following formula:

$$
\operatorname{Adj} . R^{2}=1-\frac{n-1}{n-p-1}\left(1-R^{2}\right)
$$

Where $\mathrm{n}=$ Total sample size, $\mathrm{p}=$ Number of exogenous variables and $\mathrm{R}^{2}=$ Sample R-squared.

\subsection{Measurement Design}

The disposition effect is measured using the scale proposed by Grayson (2017). This scale includes 4 items for cutting gains, 5 items for holding losses, 
and 1 item for loss aversion. Each item is measured with a five-point Likertscale starting from "strongly disagree" (coded as 1) to "strongly agree" (coded as 5).

The Big Five Inventory (BFI) test is adopted to assess personality traits. This test, developed by John, Donahue and Kentle (1991), contains 45 items, including 10 for openness, 9 for consciousness, 8 for extraversion, 10 for agreeableness, and 8 for neuroticism. Each item is measured according to a five-point Likert-scale ranging from "strongly disagree" (coded as 1) to "strongly agree" (coded as 5).

Risk-taking and risk perception are measured using the DomainSpecific Risk-Taking (DOSPERT) Scale as revised and improved by Blais and Weber (2006). The DOSPERT - financial domain questionnaire includes 6 items for risk-taking and the same for risk perception. Each item is assessed with a five-point Likert-scale starting from "extremely unlikely" (coded as 1) to "extremely likely" (coded as 5) for risk-taking and from "not risky at all" (coded as 1) to "extremely risky" (coded as 5) for risk perception. The DOSPERT questionnaire is limited to the investment sub-domain (gambling is excluded).

\subsection{Data Collection and Analysis}

This study deals with all fund management companies in Morocco managing equity and bond funds. In total, 17 companies were approached between January and March 2021. At the end of 2020, these companies managed $\$ 58$ billion and employed 68 fund managers. A total of 49 usable questionnaires are received representing $72 \%$ of all fund managers in the market. The results of the regressions presented below can be generalized since the ratio of observations to independent variables retained in these regressions is strictly greater than 5:1 according to Hair et al. (2014).

It should be noted that Moroccan mutual fund industry is the largest in North Africa in terms of assets under management.

The sample characteristics in Table 1 provide a picture of typical profile of the respondent. Thus, on average, the responding fund manager is a male with an age of about 33 years, has more than 7 years of professional experience, has a university degree, and he manages bonds rather than equities. 
Table 1. Sample Characteristics

\begin{tabular}{lllrr}
\hline & Characteristics & & $\begin{array}{c}\text { Responses } \\
\text { (in \%) }\end{array}$ \\
\hline Gender & Female & & 30.61 \\
& Male & & & 69.39 \\
Age (in years) & $\leq 30$ & Mean & 32.76 & 32.60 \\
& $31-35$ & Median & 33.50 & 34.80 \\
& $36-40$ & Stand. dev. & 4.69 & 30.40 \\
& $>40$ & & & 2.20 \\
Professional experience (in years) & $\leq 3$ (Inexperienced) & Mean & 7.37 & 22.45 \\
& $4-9$ (Experienced) & Median & 7.00 & 42.86 \\
& $\geq 10$ (Very experienced) & Stand. dev. & 4.67 & 34.69 \\
University degree & Master's degree or less & & & 67.35 \\
& Higher than master's degree & & & 32.65 \\
Type of securities managed & Equities & & 30.61 \\
& Equities and bonds & & & 16.33 \\
& Bonds & & 53.06 \\
\hline
\end{tabular}

This table reports sample characteristics of 49 fund managers having answered the survey between January and March 2021.

\subsection{Item Analysis}

To ensure the validity of the scales, the questionnaire is submitted for the opinion of a group of experts. This group is made up of general managers from five management companies, two fund managers and three experts in asset management supervision. Feedback from experts made it possible to better adapt the instructions, items and answers, and improve the quality of the questionnaire. Table 2 shows a satisfactory content validity of the scales. Values of scale content validity index (S-CVI) ${ }^{1}$, calculated using experts' feedback, are all above 0.8 according to Rubio et al. (2003) and Lynn (1986). A $\operatorname{kappa}^{2}\left(\kappa^{*}\right)$ coefficient is computed to assess experts' agreement. Table 2 shows excellent values of $\kappa^{*}$ coefficient according to Fleiss (1981) and Cicchetti and Sparrow (1981).

In order to assess the scales unidimensionality, principal component analysis (PCA) is conducted on each latent variable. This factor analysis not only made it possible to reduce the number of items per variable, but also to extract, from items dedicated to the disposition effect, two factors representing cutting gains and holding losses.

${ }^{1} S-C V I=\frac{\sum_{1}^{I}\left(\frac{n}{N}\right)_{i}}{I}$ where $\mathrm{I}$ is the number of items, $\mathrm{n}$ is the number of experts in agreement and $\mathrm{N}$ is the total number of experts.

${ }^{2} \kappa^{*}=\frac{\left(\frac{n}{N}-P_{c}\right)}{\left(1-P_{C}\right)}$ where $\mathrm{P}_{\mathrm{c}}=\frac{N !}{n ! \times(N-n) !} \times 0,5^{N}$ is the probability of chance agreement. 
Internal consistency is assessed using Cronbach's alpha and inter-item correlation, as the case may be. Table 2 shows that Cronbach's alpha $\geq 0.65$, according to DeVellis (2011), except for holding losses and risk perception with values close to 0.65 . However, internal consistency is satisfactory for the scales evaluating these two latent variables according to Corbière and Larivière (2014). Concerning risk-taking, internal consistency is assessed using inter-item correlation according to Clark and Watson (1995) and Pallant (2016). Inter-item correlation shows a value of 0.48 confirming a satisfactory internal consistency for this scale according to the range recommended by Clark and Watson (1995).

Table 2. Dimensionality, Reliability and Validity of the Scales

\begin{tabular}{llccccc}
\hline & $\begin{array}{c}\mathbf{N}^{\circ} \text { of scale } \\
\text { Items }\end{array}$ & $\begin{array}{c}\mathbf{N}^{\circ} \text { of items } \\
\text { after PCA }\end{array}$ & $\mathbf{S}$ - CVI & $\boldsymbol{\kappa}^{*}$ & IC \\
\hline $\mathbf{1}$ & Cutting gains & 4 & 2 & 1 & 1 & 0.70 \\
$\mathbf{2}$ & Holding losses & 5 & 3 & 0.89 & 0.82 & 0.64 \\
$\mathbf{3}$ & Extraversion & 8 & 3 & 1 & 1 & 0.77 \\
$\mathbf{4}$ & Neuroticism & 8 & 3 & 1 & 1 & 0.75 \\
$\mathbf{5}$ & Openness & 10 & 3 & 1 & 1 & 0.85 \\
$\mathbf{6}$ & Agreeableness & 10 & 3 & 1 & 1 & 0.69 \\
$\mathbf{7}$ & Conscientiousness & 9 & 3 & 1 & 1 & 0.76 \\
$\mathbf{8}$ & Risk-taking & 6 & 2 & 1 & 1 & 0.48 \\
$\mathbf{9}$ & Risk perception & 6 & 2 & 1 & 1 & 0.64 \\
\hline
\end{tabular}

This table shows results of dimensionality, Reliability and Validity Analysis. PCA: Principal Component Analysis; S-CVI: Scale Content Validity Index; IC: Internal Consistency

\subsection{Data Summary}

Table 3 shows that, on average, fund managers are characterized by high openness, agreeableness, risk-taking, risk perception, cutting gains, and holding losses. They show low scores on neuroticism and conscientiousness.

Female fund managers and experienced ones score high on cutting gains and holding losses respectively, while managers of bond funds and very experienced ones score low on holding losses. Concerning personality traits, Table 3 shows high scores on neuroticism for managers of equity funds and high scores on agreeableness for female fund managers. Nonetheless, inexperienced managers display low scores on extraversion. With regard to risk attitude, inexperienced managers and those managing equity and bond funds (simultaneously) show low scores on risk-taking and risk perception respectively, while female fund managers display high scores on risk perception. 
Table 3. Descriptive Statistics

\begin{tabular}{|c|c|c|c|c|c|c|c|c|c|}
\hline \multicolumn{10}{|c|}{ Demographics } \\
\hline \multicolumn{2}{|c|}{ Gender } & \multicolumn{3}{|c|}{ Professional experience } & \multicolumn{3}{|c|}{$\begin{array}{c}\text { Type of managed } \\
\text { securities }\end{array}$} & \multicolumn{2}{|c|}{ University degree } \\
\hline Female & Male & Inexperienced & Experienced & $\begin{array}{c}\text { Very } \\
\text { experienced }\end{array}$ & Equities & $\begin{array}{l}\text { Equities } \\
\& \text { bonds }\end{array}$ & Bonds & $\begin{array}{c}\text { Master's } \\
\text { degree } \\
\text { or less }\end{array}$ & $\begin{array}{c}\text { Higher } \\
\text { than } \\
\text { master's } \\
\text { degree }\end{array}$ \\
\hline 3.67 & 3.13 & 3.41 & 3.24 & 3.29 & 3.27 & 3.19 & 3.35 & 3.36 & 3.16 \\
\hline 3.13 & 3.23 & 3.09 & 3.46 & 2.94 & 3.31 & 3.67 & 2.99 & 3.11 & 3.38 \\
\hline 2.93 & 2.75 & 2.58 & 2.81 & 2.94 & 2.62 & 2.96 & 2.86 & 2.95 & 2.50 \\
\hline 2.51 & 2.21 & 2.12 & 2.19 & 2.55 & 2.69 & 2.04 & 2.15 & 2.33 & 2.23 \\
\hline 3.67 & 3.88 & 3.67 & 3.94 & 3.76 & 4.00 & 3.83 & 3.71 & 3.80 & 3.85 \\
\hline 4.49 & 4.06 & 4.36 & 4.29 & 3.96 & 4.00 & 4.25 & 4.28 & 4.17 & 4.23 \\
\hline 2.51 & 2.25 & 2.12 & 2.27 & 2.55 & 2.69 & 2.04 & 2.22 & 2.38 & 2.23 \\
\hline 3.63 & 3.78 & 3.27 & 3.88 & 3.85 & 3.67 & 3.88 & 3.73 & 3.68 & 3.84 \\
\hline 3.50 & 3.16 & 3.27 & 3.26 & 3.26 & 3.20 & 2.88 & 3.42 & 3.27 & 3.25 \\
\hline
\end{tabular}

This table illustrates means and standard deviations of dependent and independent variables. 


\section{Results}

The factor analysis, performed as part of the item analysis, enabled us to extract, from the scale dedicated to the disposition effect, two independent variables (very weak Spearman's rank correlation $\mathrm{r}=0.040$, and not significant $p$-value $=0.782$ ), namely cutting gains and holding losses. This finding is in line with previous works (Cecchini et al., 2019; Grayson, 2017; Frydman et al., 2014). Indeed, these authors also found that cutting gains and holding losses are two uncorrelated biases. Based on this result, this paper focuses on cutting gains and holding losses as two independent biases instead of considering them as two components of a single bias.

\subsection{Cutting Gains}

Results in Table 4 show a significant effect of risk perception $\left(2^{\text {nd }}, 4^{\text {th }}\right.$ and $5^{\text {th }}$ model $)$ and gender $\left(3^{\text {rd }}, 4^{\text {th }}\right.$ and $5^{\text {th }}$ model $)$ on cutting gains. Personality traits $\left(1^{\text {st }}\right.$ model $)$ do not explain cutting gains.

Risk perception shows a positive effect on cutting gains. This result suggests that fund managers with high risk perception scores tend to avoid regret, and they prefer selling their winning positions as soon as possible. This finding is consistent with prospect theory predictions. Moreover, female fund managers are more prone to cutting gains. Table 4 shows a highly significant effect of female on cutting gains. This result confirms the descriptive statistics shown in Table 3.

The results in Table 4 suggest a significant moderating effect of risk perception on the association between neuroticism and cutting gains. Neurotic fund managers are most likely to act impulsively by quickly selling their positions, especially their losing ones. However, in choices involving gains, a high-risk perception would push neurotic fund managers to tend to hold onto their winning positions longer. Figure 1 illustrates the moderating role of risk perception in the association between neuroticism and cutting gains. 
Table 4. Multivariate Regressions on Cutting Gains

\begin{tabular}{|c|c|c|c|c|c|}
\hline & $\begin{array}{c}1 \\
\text { Personality } \\
\text { traits (PT) } \\
\end{array}$ & $\begin{array}{c}2 \\
\text { Risk attitude } \\
\text { (RA) } \\
\end{array}$ & $\begin{array}{c}3 \\
\text { Demographics } \\
\text { (D) } \\
\end{array}$ & $\begin{array}{c}4 \\
\text { PT, RA and } \\
\text { D } \\
\end{array}$ & $\begin{array}{c}5 \\
\text { PT, } \\
\text { RA, D } \\
\text { and } \mathbf{P T} \times \mathbf{R A} \\
\end{array}$ \\
\hline Constant & $\begin{array}{l}2.612 * * * \\
(0.000)\end{array}$ & $\begin{array}{c}2.196 * * * \\
(0.000)\end{array}$ & $\begin{array}{c}3.132 * * * \\
(0.000)\end{array}$ & $\begin{array}{c}2.531 * * * \\
(0.000)\end{array}$ & $\begin{array}{l}-0.130 \\
(0.260)\end{array}$ \\
\hline $\begin{array}{l}\text { Extraversion } \\
\text { Neuroticism } \\
\text { Openness }\end{array}$ & & & & & \\
\hline $\begin{array}{l}\text { Agreeableness } \\
\text { Conscientiousness }\end{array}$ & $\begin{array}{c}0.159 \\
(0.257)\end{array}$ & & & & \\
\hline $\begin{array}{l}\text { Risk-taking } \\
\text { Risk perception }\end{array}$ & & $\begin{array}{l}0.230 * \\
(0.057)\end{array}$ & & $\begin{array}{l}0.190^{*} \\
(0.089)\end{array}$ & $\begin{array}{c}0.257 * * \\
(0.026)\end{array}$ \\
\hline $\begin{array}{l}\text { Gender - Female } \\
\text { Professional } \\
\text { experience } \\
\text { University degree }\end{array}$ & & & $\begin{array}{c}0.653 * * * \\
(0.006)\end{array}$ & $\begin{array}{l}0.589^{* *} \\
(0.012)\end{array}$ & $\begin{array}{c}0.567 * * * \\
(0.009)\end{array}$ \\
\hline $\begin{array}{l}\text { Neuroticism } \times \text { Risk } \\
\text { perception }\end{array}$ & & & & & $\begin{array}{c}-0.327 * * \\
(0.034) \\
\end{array}$ \\
\hline$R^{2}$ & 0.025 & 0.075 & 0.153 & 0.206 & 0.308 \\
\hline Adjusted $R^{2}$ & 0.005 & 0.056 & 0.134 & 0.171 & 0.259 \\
\hline$F$-statistics & $\begin{array}{c}1.222 \\
(0.275)\end{array}$ & $\begin{array}{l}3.823 * \\
(0.057)\end{array}$ & $\begin{array}{l}8.282 * * * \\
(0.006)\end{array}$ & $\begin{array}{c}5.833 * * * \\
(0.006)\end{array}$ & $\begin{array}{c}6.239 * * * \\
(0.001)\end{array}$ \\
\hline
\end{tabular}

This table shows results of cross-sectional multiple regressions of cutting gains on personality traits, risk attitude, and demographic variables using the best model selection procedure based on adjusted $\mathrm{R}^{2}$ criterion.

1: regression of cutting gains on personality traits. 2: regression of cutting gains on risk attitude. 3: regression of cutting gains on demographic variables. 4: regression of cutting gains on all independent variables. 5: $4^{\text {th }}$ regression integrating the interaction terms "personality traits $\times$ risk attitude". 


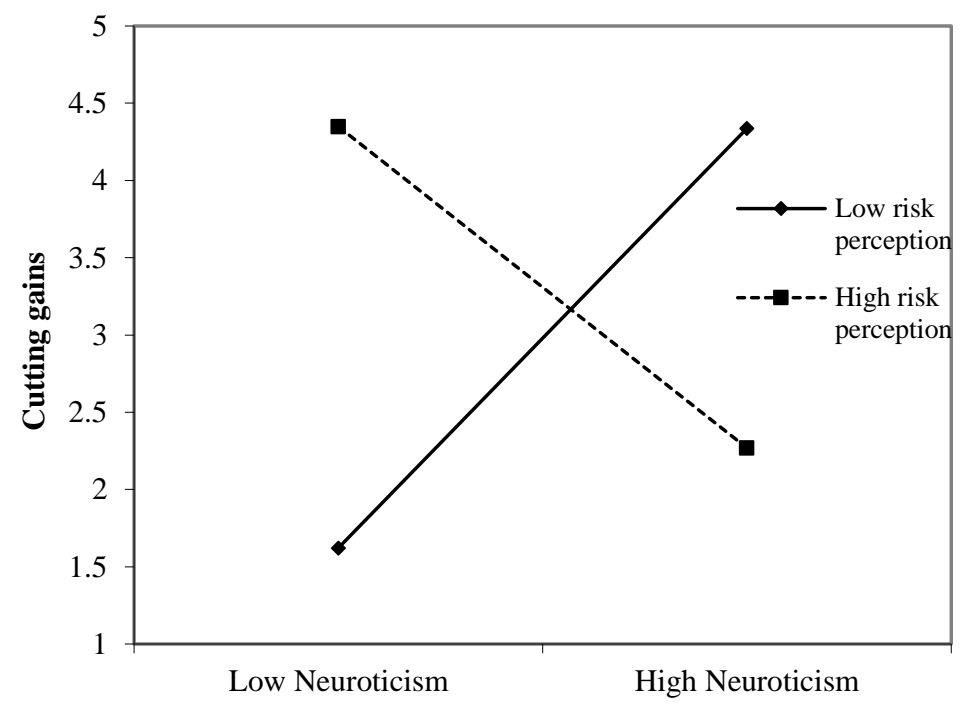

Figure 1. The Moderating Role of Risk Perception in the Association between Neuroticism and Cutting Gains

\subsection{Holding Losses}

Concerning holding losses, Table 5 shows a significant effect of extraversion and openness $\left(5^{\text {th }}\right.$ model $)$, risk-taking $\left(5^{\text {th }}\right.$ model $)$, professional experience, and university degree $\left(3^{\text {rd }}, 4^{\text {th }}\right.$ and $5^{\text {th }}$ model $)$ on holding losses.

Extraversion is negatively related to holding losses. Generally, extravert individuals are portrayed as energetic, sociable, talkative, and friendly. In order to anticipate market trends, it is important for the fund manager to be close to the market and to have privileged relationships with market participants. Characterized by the ability to make contact easily, extravert fund managers are less prone to holding losses bias. Similarly, openness is negatively related to holding losses. Openness is associated with individuals of good intellectual level, curious, with great imagination and inventiveness. Therefore, it is obvious that open fund managers are less prone to holding losses bias.

Risk-taking shows a negative effect on holding losses. This finding suggests that high risk-taking fund managers tend to take additional risk and prefer to sell their losing positions. Regarding the impact of demographic variables, the results present a significant effect of professional experience and university degree on holding losses. Fund managers with master's degree or less tend not to exhibit holding losses bias. In contrast, experienced fund managers are more prone to holding losses bias than inexperienced and very experienced ones. These results relating to demographic variables confirm the descriptive statistics shown in Table 3. 
The results also show a significant effect of interaction terms on holding losses. Thus, the interaction term of openness and risk-taking provide a highly significant negative effect on holding losses. Figure 2 indicates that high risk-taking fund managers with a high level of openness are less prone to exhibit holding losses. Fund managers who score high on openness, which is associated with good intellectual level and great imagination and inventiveness, when they take more risks, tend not to hold their losing positions too long. Table 5 also presents a significant moderating effect of risk-taking on the association between agreeableness and holding losses. Figure 2 shows that high risk-taking fund managers with high level of agreeableness tend to display holding losses bias. Agreeableness is associated to courtesy, generosity, and warm relationships. In order to maintain a good self-image by showing good performance, fund managers with high scores on agreeableness and risk-taking tend to hold their losing positions too long.
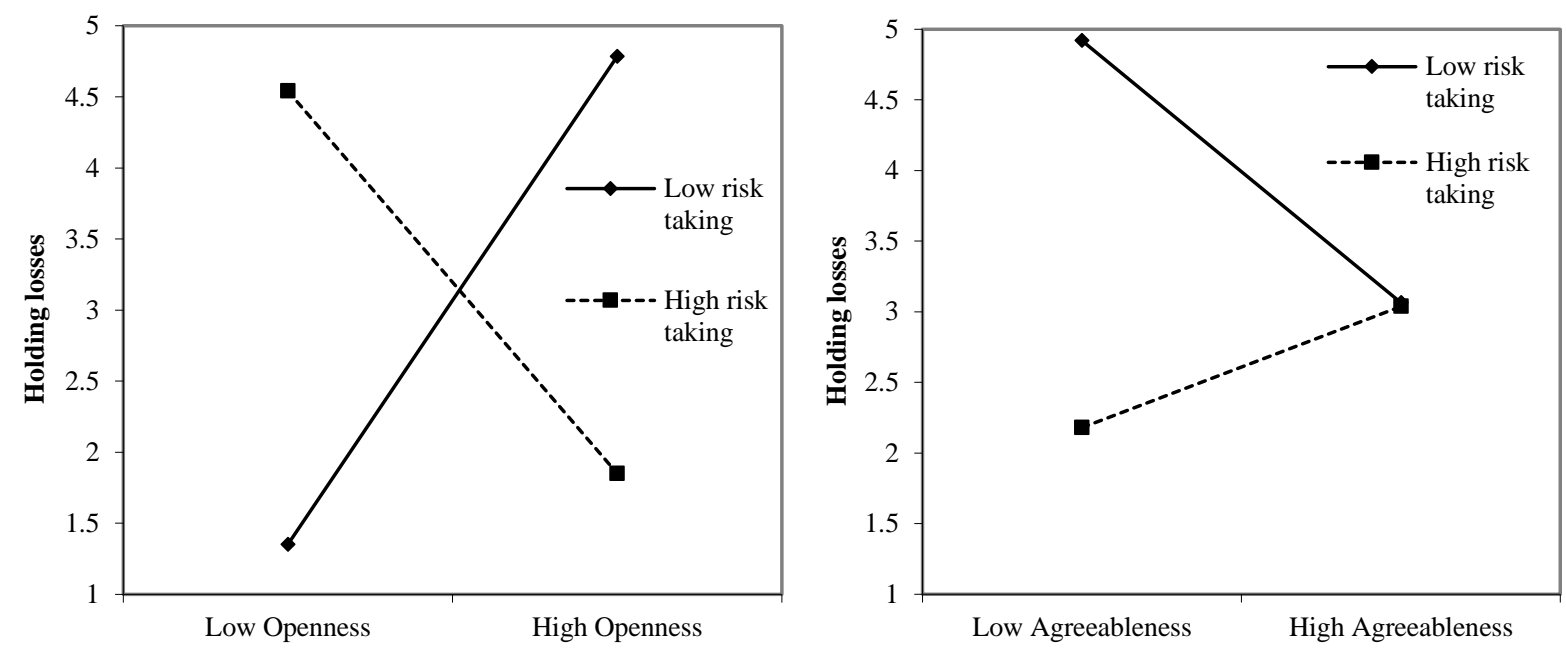

Figure 2. The Moderating Role of Risk-Taking in the Association between Personality Traits and holding losses 
Table 5. Multivariate Regressions on Holding Losses

\begin{tabular}{|c|c|c|c|c|c|}
\hline & $\begin{array}{c}1 \\
\text { Personality } \\
\text { traits (PT) }\end{array}$ & $\begin{array}{c}2 \\
\text { Risk attitude } \\
\text { (RA) }\end{array}$ & $\begin{array}{c}3 \\
\text { Demographics } \\
\text { (D) }\end{array}$ & $\begin{array}{c} \\
\text { PT, RA } \\
\text { and D }\end{array}$ & $\begin{array}{c}\mathbf{5} \\
\text { PT, } \mathbf{R A}, \mathbf{D} \\
\text { and } \mathbf{P T} \times \mathbf{R A}\end{array}$ \\
\hline Constant & $\begin{array}{c}3.424 * * * \\
(0.000)\end{array}$ & $\begin{array}{c}3.348 * * * \\
(0.000)\end{array}$ & $\begin{array}{c}3.057 * * * \\
(0.000)\end{array}$ & $\begin{array}{c}3.057 * * * \\
(0.000)\end{array}$ & $\begin{array}{l}-0.151 \\
(0.379)\end{array}$ \\
\hline Extraversion & & & & & $\begin{array}{c}-0.282 * * * \\
(0.007)\end{array}$ \\
\hline Neuroticism & $\begin{array}{l}-0.124 \\
(0.259)\end{array}$ & & & & $\begin{array}{c}0.148 \\
(0.188)\end{array}$ \\
\hline Openness & & & & & $\begin{array}{l}-0.226^{*} \\
(0.097)\end{array}$ \\
\hline $\begin{array}{l}\text { Agreeableness } \\
\text { Conscientiousness }\end{array}$ & & & & & \\
\hline $\begin{array}{l}\text { Risk-taking } \\
\text { Risk perception }\end{array}$ & & $\begin{array}{l}-0.035 \\
(0.735)\end{array}$ & & & $\begin{array}{l}-0.190^{*} \\
(0.058)\end{array}$ \\
\hline $\begin{array}{l}\text { Gender } \\
\text { Professional experience - } \\
\text { Inexperienced } \\
\text { Professional experience - } \\
\text { Experienced } \\
\text { University degree - Master's } \\
\text { degree or less }\end{array}$ & & & $\begin{array}{c}0.323 \\
(0.191) \\
0.687 * * * \\
(0.002) \\
-0.397 * * \\
(0.043)\end{array}$ & $\begin{array}{c}0.323 \\
(0.191) \\
0.687 * * * \\
(0.002) \\
-0.397 * * \\
(0.043)\end{array}$ & $\begin{array}{c}0.275 \\
(0.289) \\
0.785 * * * \\
(0.000) \\
-0.387 * * \\
(0.031)\end{array}$ \\
\hline $\begin{array}{l}\text { Openness } \times \text { Risk-taking } \\
\text { Agreeableness } \times \text { Risk-taking }\end{array}$ & & & & & $\begin{array}{c}-0.459 * * * \\
(0.004) \\
0.226^{*} \\
(0.075)\end{array}$ \\
\hline$R^{2}$ & 0.028 & 0.003 & 0.241 & 0.241 & 0.512 \\
\hline Adjusted $R^{2}$ & 0.007 & -0.019 & 0.189 & 0.189 & 0.393 \\
\hline$F$-statistics & $\begin{array}{c}1.309 \\
(0.259)\end{array}$ & $\begin{array}{c}0.116 \\
(0.735)\end{array}$ & $\begin{array}{c}4.646 * * * \\
(0.007)\end{array}$ & $\begin{array}{c}4.646 * * * \\
(0.007)\end{array}$ & $\begin{array}{c}4.305 * * * \\
(0.001)\end{array}$ \\
\hline
\end{tabular}

This table shows results of cross-sectional multiple regressions of holding losses on personality traits, risk attitude, and demographic variables using the best model selection procedure based on adjusted $\mathrm{R}^{2}$ criterion.

1: regression of holding losses on personality traits. 2: regression of holding losses on risk attitude. 3: regression of holding losses on demographic variables. 4: regression of holding losses on all independent variables. 5: $4^{\text {th }}$ regression integrating the interaction terms "personality traits $\times$ risk attitude".

\section{Conclusion}

The results of this study on fund managers' behavior call for several conclusions. Firstly, extraversion, openness, risk-taking and master's degree, or less, holders are negatively associated with holding losses. Experienced fund managers are more prone to holding losses. Risk-taking plays a significant negative moderating role in the association between openness and holding losses. Similarly, risk-taking moderates negatively the relation 
between agreeableness and holding losses. Secondly, female fund managers and managers with high scores in risk perception are more prone to cutting gains. Risk perception moderates negatively the association between neuroticism and cutting gains. Hence, the results allow us to draw up the typical profile of a fund manager who is prone or less prone to holding losses and cutting gains.

This paper contributes to the literature in three ways. First, it provides further evidence that holding losses and cutting gains are indeed two independent biases rather than two building blocks of the same bias: two uncorrelated biases explained by different sets of factors. Second, this paper contributes to the very few studies on the personality traits and behavioral biases of professional investors. Third, the results of this study may have important managerial implications in fund management companies. On the one hand, management companies may set up fund management rules, like stop-loss and stop-gain strategies, adapted to the psychological and demographic profile of each fund manager. Furthermore, these companies may improve their recruiting procedures using the insights of this study.

Finally, it will be interesting to test the moderating role that the management company's organization, such as decision-making procedures and monitoring procedures, could play in the intensity of the association between personality traits and both holding losses and cutting gains.

\section{References:}

1. Ahmad, F. (2020). Personality traits as predictor of cognitive biases: moderating role of risk-attitude. Qualitative Research in Financial Markets, 12(4), 465-484. https://doi.org/10.1108/QRFM-10-20190123

2. Blais, A. \& Weber, E. U. (2006). A Domain-Specific Risk-Taking (DOSPERT) scale for adult populations. Judgment and Decision Making, 1(1), 33-47.

3. Braga, R. \& Fávero, L. P. L. (2017). Disposition Effect and Tolerance to Losses in Stock Investment Decisions: An Experimental Study. Journal of Behavioral Finance, 18(3), 271-280. https://doi.org/10.1080/15427560.2017.1308946

4. Cecchini, M., Bajo, E., Russo, P. M. \& Sobrero, M. (2019). Individual Differences in the Disposition Effect. Journal of Behavioral Finance, 20(1), 107-126. https://doi.org/10.1080/15427560.2018.1492579

5. Cheng, T. Y., Lee, C. I. \& Lin, C. H. (2013). An examination of the relationship between the disposition effect and gender, age, the traded security, and bull-bear market conditions. Journal of Empirical Finance, 21(1), 195-213.

https://doi.org/10.1016/j.jempfin.2013.01.003 
6. Cicchetti, D. V. \& Sparrow, S. A. (1981). Developing criteria for establishing interrater reliability of specific items: Applications to assessment of adaptive behavior. American Journal of Mental Deficiency, 86(2), 127-137.

7. Clark, L. A. \& Watson, D. (1995). Constructing Validity: Basic Issues in Objective Scale Development. Psychological Assessment, 7(3), 309-319.

8. Corbière, M. \& Larivière, N. (2014). Méthodes qualitatives, quantitatives et mixtes: dans la recherche en sciences humaines, sociales et de la santé. Québec: Presses de l'Université du Québec (PUQ).

9. Cueva, C., Iturbe-Ormaetxe, I., Ponti, G. \& Tomás, J. (2019). An experimental analysis of the disposition effect: Who and when? Journal of Behavioral and Experimental Economics, 81, 207-215. https://doi.org/10.1016/j.socec.2019.06.011

10. DeVellis, R. F. (2011). Scale Development: Theory and Applications (Volume 26). Sage Publications, Inc., Thousand Oaks.

11. Durand, R. B., Newby, R., Peggs, L. \& Siekierka, M. (2013). Personality. Journal of Behavioral Finance, 14(2), 116-133. https://doi.org/10.1080/15427560.2013.791294

12. Fleiss, J. L. (1981). Statistical Methods for Rates and Proportions (1st ed.). London: John Wiley \& Sons, Inc.

13. Frydman, C., Barberis, N., Camerer, C., Bossaerts, P. \& Rangel, A. (2014). Using Neural Data to Test a Theory of Investor Behavior: An Application to Realization Utility. The Journal of Finance, LXIX (2), 907-946. https://doi.org/10.1111/jofi.12126

14. Grayson, P. (2017). The Disposition Effect, Trading Biases, and Cognitive Reappraisal - PhD Thesis. The Open University.

15. Hair, J. F., Black, W. C., Babin, B. J. \& Anderson, R. E. (2014). Multivariate Data Analysis. (Pearson, Ed.) (7th ed.). Harlow.

16. Jin, L. \& Scherbina, A. (2011). Inheriting losers. Review of Financial Studies, 24(3), 786-820. https://doi.org/10.1093/rfs/hhq084

17. John, O. P., Donahue, E. M. \& Kentle, R. L. (1991). The Big-Five Inventory-Version 4a and 54. Berkeley, CA: Berkeley Institute of Personality and Social Research. University of California.

18. Kahneman, D. \& Tversky, A. (1979). Prospect Theory: An Analysis of Decision under Risk. Econometrica, 47(2), 263-291. https://doi.org/10.1111/j.1536-7150.2011.00774.x

19. Lynn, M. R. (1986). Determination and Quantification of Content Validity. Nursing Research, 35(6), 382-385. https://doi.org//10.1097/00006199-198611000-00017

20. Odean, T. (1998). Volume, Volatility, Price and Profit When All 
Traders Are Above Average. The Journal of Finance, LIII (6), 1887 1934. https://doi.org/10.1111/0022-1082.00078

21. Oreng, M., Yoshinaga, C. E. \& Eid Junior, W. (2021). Disposition effect, demographics and risk taking. RAUSP Management Journal, ahead-of-print (ahead-of-print). https://doi.org/10.1108/rausp-082019-0164

22. Pallant, J. (2016). SPSS Survival Manual: A Step by Step Guide to Data Analysis Using SPSS Program. (McGraw-Hill Education, Ed.) (6th ed.). London: Open University Press.

23. Rau, H. A. (2014). The disposition effect and loss aversion: Do gender differences matter? Economics Letters, 123(1), 33-36. https://doi.org/10.1016/j.econlet.2014.01.020

24. Rubio, D. M., Berg-weger, M., Tebb, S. S., Lee, E. S. \& Rauch, S. (2003). Objectifying content validity: in social work research. Social Work Research, 27(2), 94-104. https://doi.org/doi.org/10.1093/swr/27.2.94

25. Shefrin, H. \& Statman, M. (1985). The Disposition to Sell Winners Too Early and Ride Losers Too Long: Theory and Evidence. The Journal of Finance, 40(3), 777-790. https://doi.org/10.1111/j.15406261.1985.tb05002.x

26. Singal, V. \& Xu, Z. (2011). Selling winners, holding losers: Effect on fund flows and survival of disposition-prone mutual funds. Journal of Banking and Finance, 35(10), 2704-2718. https://doi.org/10.1016/j.jbankfin.2011.02.027

27. Summers, B. \& Duxbury, D. (2012). Decision-dependent emotions and behavioral anomalies. Organizational Behavior and Human Decision Processes, 118(2), 226-238. https://doi.org/10.1016/j.obhdp.2012.03.004

28. Thaler, R. H. (1985). Mental accounting and consumer choice. Marketing Science, 4(3), 199-214. https://doi.org/10.1287/mksc. 1070.0330

29. Tupes, E. C. \& Christal, R. E. (1992). Recurrent Personality Factors Based on Trait Ratings. Journal of Personality, 60(2), 225-251. https://doi.org/doi.org/10.1111/j.1467-6494.1992.tb00973.x

30. Weber, M. \& Welfens, F. (2007). An Individual Level Analysis of the Disposition Effect: Empirical and Experimental Evidence (Sonderforschungsbereich 504 No. 07-45). https://doi.org/10.2307/j.ctv5rf757.12

31. Wulfmeyer, S. (2016). Irrational Mutual Fund Managers: Explaining Differences in Their Behavior. Journal of Behavioral Finance, 17(2), 99-123. https://doi.org/10.1080/15427560.2016.1133621 